\title{
Fermentasi Produksi Asam Sitrat menggunakan Aspergillus Niger ATCC 16404 dengan Substrat Hidrolisat Cair Limbah Padat Industri Brem
}

\author{
Gede Asstaradi Kusuma, Nyoman Semadi Antara*, Ni Putu Suwariani \\ PS Teknologi Industri Pertanian, Fakultas Teknologi Pertanian, Universitas Udayana, Kampus Bukit \\ Jimbaran, Badung, Kode pos : 80361; Telp/Fax : (0361) 701801.
}

Diterima 15 Juli 2019 / Disetujui 27 Agustus 2019

\begin{abstract}
Dregs of solid waste brem industry contained 12 percent of sugar and 10,8 percent of starch. Component contained in the dregs are expected to produce citric acid. The aims of this study were to determine the effect of static cultivation on the production of citric acid from liquid hydrolyzate brem waste by using Aspergillus niger. The experimental design used in this study was a simple randomized block design $(R A K)$, which the static cultivations $(0,1,2,3$ days) as a treatment. The results showed that the static cultivation treatment significantly affected the level of acidity $(\mathrm{pH})$, total soluble solids, biomass, reducing sugar, calcium citrate, citric acid and yield. The static cultivation for 1 day was the best treatment to produce Ca-citrate which the production level was 3,84 $\pm 0,05 \mathrm{~g} / \mathrm{L}$. By the stoichiometry method the citric acid production could be calculated, which equal to 2,12 $\pm 0,03 \mathrm{~g} / \mathrm{L}$.

Keywords: Aspergillus niger, dregs of brem, static cultivation, Ca-citrate, citric acid
\end{abstract}

\begin{abstract}
ABSTRAK
Ampas limbah padat industri brem mengandung 12 persen gula dan 10,8 persen pati. Komponen yang terkandung dalam ampas diharapkan menghasilkan asam sitrat. Tujuan dari penelitian ini adalah untuk mengetahui pengaruh kultivasi statis terhadap produksi asam sitrat dari hidrolisat cair limbah padat brem menggunakan Aspergillus niger. Desain eksperimental yang digunakan dalam penelitian ini adalah rancangan acak kelompok sederhana (RAK), dimana kultivasi statis $(0,1,2,3$ hari) sebagai perlakuan. Hasil penelitian ini menunjukkan bahwa perlakuan kultivasi statis berpengaruh nyata terhadap derajat keasaman $(\mathrm{pH})$, total padatan terlarut, gula reduksi, kalsium sitrat, asam sitrat, dan yield. Perlakuan kultivasi statis 1 hari adalah perlakuan yang terbaik untuk memproduksi Ca-sitrat dimana hasil produksinya adalah $3,84 \pm 0,05 \mathrm{~g} / \mathrm{L}$. Dengan metode perhitungan stoikiometri asam sitrat yang terproduksi akan terhitung, sejumlah 2,12 $\pm 0,03 \mathrm{~g} / \mathrm{L}$.
\end{abstract}

Kata kunci: Aspergillus niger, limbah brem, kultivasi statis, Ca-sitrat, asam sitrat

\footnotetext{
*Korespondensi Penulis:

Email : semadi.antara@unud.ac.id
} 


\section{PENDAHULUAN}

Limbah padat brem merupakan ampas hasil sisa dari pengepresan tape ketan pada pembuatan brem yang masih mengandung pati dan gula. Menurut Winarno (1993), limbah padat brem sebagian besar baru dimanfaatkan untuk pakan ternak saja, maka dari itu pemanfaatan limbah padat brem belum berjalan secara optimal. Hal ini menyebabkan sebagian besar sisa dari limbah padat brem yang tidak dimanfaatkan dibuang begitu saja sehingga menimbulkan bau busuk dan menyebabkan terjadinya pencemaran pada lingkungan. Selanjutnya dinyatakan bahwa dalam pengolahan brem akan diperoleh sari tape (cairan tape) sebanyak 75 persen dari berat tape, sedangkan limbah atau ampasnya sebesar 25 persen.

Seiring dengan perkembangan teknologi yang semakin meningkat, ampas brem dapat dimanfaatkan sebagai bahan baku pembuatan asam sitrat, mengingat kandungan gula yang terdapat dalam limbah padat brem cukup banyak yaitu 12 persen (Ulfa, 1996). Salah satu inovasi yang dapat dilakukan yakni memanfaatkan limbah padat brem untuk diolah menjadi asam sitrat mengingat kandungan gula yang terdapat dalam limbah padat brem cukup banyak dan senyawa karbon utama dalam memproduksi asam sitrat adalah glukosa.

Pemanfaatan asam sitrat cukup besar dalam bidang industri, dengan persentase sebagai berikut : industri makanan dan minuman sekitar 70 persen, industri farmasi 12 persen, dan sisanya 18 persen digunakan pada berbagai industri. Kegunaan lain dari asam sitrat yaitu sebagai pengawet, pencegah kerusakan warna dan aroma, menjaga turbiditas, penghambat oksidasi, penghasil warna gelap pada kembang gula, selai dan jelly, dan pengatur $\mathrm{pH}$. Berdasarkan keadaan tersebut, banyak penelitian dilakukan untuk mendapatkan asam sitrat dengan kualitas baik dan rendemen tinggi (Sumo et al., 1993).
Kapang Aspergillus niger merupakan mikroorganisme yang dapat tumbuh dan banyak digunakan secara komersial dalam produksi asam sitrat, asam glukonat, dan beberapa enzim seperti pektinase dan amilase (Broekhuijsen et al., 1993; Okada, 1985). A.niger mampu mensintesis asam sitrat dalam medium fermentasi ekstraseluler dengan konsentrasi yang cukup tinggi, jika dibiakkan dalam media yang kadar garamnya rendah dan mengandung gula sebagai sumber karbon (Hang et al., 1977; Ji et al., 1992).

Produksi asam sitrat akan optimal dengan $\mathrm{pH}$ sekitar 2. Jika kondisi tersebut tidak diperoleh, hasil produksi asam sitrat akan berkurang (Mattey, 1992). Papagianni (1995) dan Papagianni et al., (1999) melaporkan bahwa $\mathrm{pH}$ mempengaruhi morfologi dan produktivitas asam sitrat dari Aspergillus niger dari hasil data kuantitatif. Morfologi dengan agregat yang kecil dan filamen yang pendek berkaitan dengan meningkatnya produksi asam sitrat pada $\mathrm{pH}$ sekitar 2,0 \pm 0,2. Pada pH 1,6 morfologi akan berkembang abnormal (bulbous hyphae) dan produksi asam sitrat akan menurun secara drastis.

Menurut Suwariani (2016), kultivasi statis pertumbuhan mikrobia pada medium fermentasi adalah untuk memberikan waktu beradaptasi sebelum proses fermentasi secara submerged dilakukan, sehingga dengan adanya fase adaptasi tersebut maka fase pertumbuhan akan lebih maksimal. Adaptasi dilakukan karena hifa Aspergillus niger rentan rapuh pada fase pertumbuhan, sehingga perlu waktu adaptasi sebelum proses fermentasi dengan cara pengadukan.

Ali et al (2002), menyatakan proses fermentasi kultur terendam (submerged) pada molase menggunakan Aspergillus niger secara batch dengan menggunakan parameter proses fermentasi, yaitu : laju oksigen, $\mathrm{pH}$, temperatur inkubasi yang digunakan pada bahan baku molase dengan kadar 15 persen dan proses dijalankan dalam 144 jam, dalam 
penelitian dilakukan pengontrolan trace mineral yang ada, didapatkan asam sitrat maksimum mencapai 99,56 persen $\pm 3,5 \mathrm{~g} / \mathrm{L}$.

Penelitian ini merupakan fermentasi produksi asam sitrat menggunakan substrat hidrolisat cair limbah padat industri brem. Tujuan penelitian ini adalah untuk memperoleh produksi asam sitrat akibat perlakuan kultivasi statis. Penelitian fermentasi produksi asam sitrat dengan menggunakan substrat ampas brem juga sudah dilakukan (Wagestu et al., 2017 ; Darmataba et al., 2017).

\section{METODE PENELITIAN}

\section{Tempat dan Waktu Penelitian}

Penelitian ini dilaksanakan di Laboratorium Bioindustri dan Lingkungan, Laboratorium Analisis Pangan, dan Laboratorium Mikrobiologi Pangan Fakultas Teknologi Pertanian, Universitas Udayana. Waktu pelaksanaan penelitian dimulai dari November sampai Januari 2019.

\section{Rancangan Penelitian}

Penelitian ini menggunakan rancangan acak kelompok (RAK) sederhana dengan 1 perlakuan, yaitu kultivasi statis (F) yang terdiri dari 4 taraf yaitu F0: 0 hari statis, F1: 1 hari statis, F2: 2 hari statis, F3: 3 hari statis. Masing-masing perlakuan dibuat menjadi 4 kelompok sehingga diperoleh 16 unit percobaan dan waktu fermentasi pada masing-masing perlakuan yaitu 5 hari. Data yang diperoleh dari masing-masing perlakuan kemudian dianalisis dengan sidik ragam, apabila perlakuan berpengaruh nyata terhadap parameter yang diamati maka dilanjutkan dengan uji Duncan.

\section{Pembuatan Tepung Limbah Padat Brem}

Tahapan dalam pembuatan tepung limbah padat brem meliputi: pengeringan (oven), penggilingan dan pengayakan. Proses pengeringan limbah padat brem dilakukan dengan cara dioven pada suhu $60{ }^{\circ} \mathrm{C}$ selama 18 jam. Proses pengeringan akan menghasilkan limbah padat brem kering dengan kadar air 10 persen. Selanjutnya dilakukan proses penepungan, limbah padat brem kering diblender hingga halus. Setelah itu dilakukan proses pengayakan dengan ayakan sebesar 60 mesh (Subakti et al. 2015).

\section{Persiapan Suspensi Spora Aspergillus niger ATCC 16404}

Isolat Aspergillus niger ATCC 16404 dibuka dari media gliserol dan diremajakan dengan cara diinokulasikan kembali pada media PDA. Selanjutnya diinkubasi selama 3-4 hari pada suhu $30{ }^{\circ} \mathrm{C}$ dalam inkubator, lalu dilakukan penggoresan pada cawan petri yang telah diisi media PDA dan diinkubasi kembali selama 3-5 hari. Setelah 3-5 hari dilakukan penggoresan lagi pada media yang sama dan diinkubasi pada waktu dan suhu yang sama. Selanjutnya dilakukan penggoresan pada agar miring dan diinkubasi kembali selama 3 hari pada suhu $30{ }^{\circ} \mathrm{C}$. Kultur yang telah diinkubasi disimpan pada media tween 80 dan disebut sebagai suspensi spora. Perhitungan jumlah spora dilakukan dengan menggunakan haemocytometer modifikasi pada penelitian ini adalah pada densitas spora yaitu sebanyak $8,12 \times 10^{7}$ spora/mL. Selanjutnya suspensi spora disimpan dalam lemari es. (Suwariani, 2016 dengan modifikasi).

\section{Pembuatan Hidrolisat Limbah Padat Brem}

Tepung ampas brem ditimbang sebanyak $100 \mathrm{~g}$ kemudian dicampur dengan larutan $\mathrm{HCl} 0,75$ persen dengan perbandingan 1:4 di dalam botol sampel. Kemudian botol sampel dimasukkan ke dalam sterilizer (autoclave) dengan kondisi suhu $121{ }^{\circ} \mathrm{C}$ selama 30 menit. Setelah itu, wadah dan isinya dikeluarkan dari autoclave. Untuk mendapatkan hidrolisat cair tepung limbah padat brem dilakukan dengan cara filtrasi 
(penyaringan) menggunakan kertas saring kasar sehingga diperoleh hidrolisat cair yang siap digunakan sebagai media fermentasi. (Pertiwi et al., 2016).

\section{Fermentasi Produksi Asam Sitrat}

Tahap fermentasi dilakukan secara kultur terendam (Udin, 1986). Ke dalam media fermentasi steril diinokulasikan suspensi spora Aspergillus niger ATCC $164048,12 \times 10^{7}$ sebanyak 5 mL kemudian dilakukan fermentasi aerob dan pengadukan dengan shaker. Lama kultivasi statis yaitu 0 hari, 1 hari, 2 hari, dan 3 hari dengan suhu 30 ${ }^{\circ} \mathrm{C}$, dan dengan lama fermentasi masingmasing perlakuan selama 5 hari. Setelah fermentasi dilakukan pemisahan biomassa dengan penyaringan menggunakan kertas saring kasar untuk memisahkan cairan fermentasi dan biomassa kapang Aspergillus niger.

\section{Produksi Ca-Sitrat dan Yield Ca-Sitrat}

Kalsium sitrat diproduksi dengan metode presipitasi, dengan cara asam sitrat diendapkan dengan menambahkan $\mathrm{Ca}(\mathrm{OH})_{2}$ ke dalam cairan fermentasi sampai tercapai pH 7, kemudian campuran tersebut dipanaskan pada suhu mendidih selama 10 menit, sehingga terbentuknya endapan kalsium sitrat. Sampel yang sudah melalui proses pemanasan, kemudian didinginkan dan disentrifugasi selama 15 menit pada suhu $4{ }^{\circ} \mathrm{C}$ dengan kecepatan $5000 \mathrm{rpm}$ untuk memisahkan endapan dan filtratnya. Endapan kalsium sitrat dicuci menggunakan aquades sebanyak dua kali. Setelah melalui proses pencucian, endapan dikeringkan pada suhu $105^{\circ} \mathrm{C}$ sampai berat konstan. Endapan yang sudah kering ditimbang dan dicatat berat kalsium sitratnya. Berat kalsium sitrat yang diperoleh kemudian dikonfersikan menjadi berat asam sitrat (Azhary et al., 2013).

Yield Ca-Sitrat merupakan jumlah CaSitrat (gram) yang dapat diproduksi dari 1 gram gula melalui proses fermentasi. Yield
Ca-Sitrat (Ypcs/s) dapat dihitung dengan membagi berat Ca-sitrat yang dihasilkan dengan berat gula yang dimanfaatkan pada proses fermentasi (berat gula reduksi awal dikurangi berat gula reduksi setelah fermentasi). Secara matematis yield Ca-sitrat dapat dirumuskan sebagai berikut;

Keterangan

$$
\text { Yield Ca-Sitrat }\left(\text { Y pcs/s) }=\frac{\mathrm{a}}{\mathrm{b}-\mathrm{c}}\right.
$$

a : berat Ca-Sitrat

$\mathrm{b}$ : berat gula reduksi awal

c : berat gula reduksi setelah fermentasi

\section{Asam Sitrat dan Yield Asam Sitrat}

Perhitungan asam sitrat dilakukan berdasarkan stoikiometri dengan reaksi pembentukan kalsium sitrat sebagai berikut :

\footnotetext{
$3 \mathrm{Ca}(\mathrm{OH})_{2}+2 \mathrm{C}_{6} \mathrm{H}_{8} \mathrm{O}_{7} \longrightarrow \mathrm{Ca}_{3}\left(\mathrm{C}_{6} \mathrm{H}_{5} \mathrm{O}_{7}\right)_{2}+6 \mathrm{H}_{2} \mathrm{O}$
}

1 mol Ca-Sitrat terbentuk oleh 2 mol Asam Sitrat

Asam Sitrat

$$
\text { Produksi asam sitrat }\left(\begin{array}{l}
\frac{\mathrm{g}}{\mathrm{l}} \\
\mathrm{l}
\end{array}\right)=\frac{2 \mathrm{x} \frac{\mathrm{Wl}}{\mathrm{BMC} \text { Ca Sitrat }} \mathrm{X} \text { BM Asam Sitrat }}{\text { Vol sampel (mL) }} \times 1000
$$

Keterangan

W1 = Berat Kalsium Sitrat

$\mathrm{BM}=$ Berat Molekul

Yield asam sitrat merupakan jumlah asam sitrat (gram) yang dapat diproduksi dari 1 gram gula melalui proses fermentasi. Yield asam sitrat (Ypas/s) dapat dihitung dengan membagi berat asam sitrat yang dihasilkan dengan berat gula yang dimanfaatkan pada proses fermentasi (berat gula reduksi awal dikurangi berat gula reduksi setelah fermentasi). Secara matematis yield asam sitrat dapat dirumuskan sebagai berikut;

$$
\text { Yield asam sitrat (Ypas/s) }=\frac{\mathrm{a}}{\mathrm{b}-\mathrm{c}}
$$

\section{Keterangan}

a : berat asam sitrat

$\mathrm{b}$ : berat gula reduksi awal

c : berat gula reduksi setelah fermentasi

\section{Penentuan Derajat Keasaman}


Pengukuran derajat keasaman $(\mathrm{pH})$ dilakukan dengan $\mathrm{pH}$ meter (Sudarmadji et al., 1997). Alat pH meter yang telah dinyalakan dan distabilkan kemudian distandarisasi dengan larutan buffer pada $\mathrm{pH}$ 4 dan $\mathrm{pH}$ 7. Elektroda dibilas dan dikeringkan dengan kertas tisu kemudian dicelupkan ke dalam sampel. Nilai $\mathrm{pH}$ meter dibiarkan hingga menunjukkan suatu angka yang stabil, angka ini dicatat sebagai nilai $\mathrm{pH}$ terukur.

\section{Penentuan Total Padatan Terlarut}

Pengukuran total padatan terlarut dapat diukur dengan menggunakan refraktometer. Pertama alat refraktometer dibersihkan dan distandarisasi dengan aquades. Setelah itu sampel yang telah difermentasi diambil menggunakan pipet tetes, kemudian diteteskan pada refraktometer. Angka yang ditunjukkan oleh refraktometer diamati dan hasil tersebut dicatat (Harijono et al., 2001).

\section{Penentuan Gula Reduksi}

Penentuan gula reduksi dapat dilakukan dengan cara kimiawi yaitu metode SomogyiNelson (Sudarmadji et al., 1970). Sampel ditimbang sebanyak $\pm 2 \mathrm{~g}$ yang telah dihidrolisis asam, disaring dengan kertas saring, lalu filtrat yang diperoleh dilakukan pengujian kadar gula reduksi. Sebanyak 500 nm filtrat yang dihasilkan ditambahkan dengan $500 \mu \mathrm{L}$ larutan reagen Nelson. Lalu dipanaskan \pm 15 menit sampai mendidih. Kemudian didinginkan \pm 10 menit, ditambahkan arsenomolibdat sebanyak 500 $\mu \mathrm{L}$ dan aquades 3,5 mL. Selanjutnya divortex dan dibaca pada spektrofotometer dengan panjang gelombang $\lambda 540 \mathrm{~nm}$ untuk mendapatkan nilai absorbansinya. Adapun dapat dihitung dengan perhitungan yaitu;

$$
\text { persen Gula }=\frac{\text { Glukosa }(\mathrm{mg}) \times \text { Pengenceran }}{\text { Berat sampel }(\mathrm{mg})} \times 100 \text { persen }
$$

\section{Penentuan Biomassa dan Yield Biomassa}

Pengukuran biomassa dapat dilakukan dengan menggunakan kertas saring. Untuk setiap sampel yang diambil, kertas saring kering yang sudah ditimbang sebelumnya digunakan untuk menyaring hasil fermentasi asam sitrat. Endapan yang dihasilkan dicuci tiga kali menggunakan air suling dan dikeringkan pada suhu $120{ }^{\circ} \mathrm{C}$ selama 6 jam hingga berat konstan, kemudian dibiarkan dingin dan berat akhir dicatat. Berat biomassa ditentukan dengan mengurangi berat kertas saring dengan massa sel dan berat kertas saring awal. (Betiku \& Adesina, 2013).

Yield biomassa merupakan jumlah biomassa (gram) yang dapat diproduksi dari 1 gram gula melalui proses fermentasi. Yield biomassa $(\mathrm{Yx} / \mathrm{s})$ dapat dihitung dengan membagi berat biomassa yang dihasilkan dengan berat gula yang dimanfaatkan pada proses fermentasi (berat gula reduksi awal dikurangi berat gula reduksi setelah fermentasi). Secara matematis yield biomassa dapat dirumuskan sebagai berikut;

$$
\text { Yield biomassa }(\mathrm{Yx} / \mathrm{s})=\frac{\mathrm{a}}{\mathrm{b}-\mathrm{c}}
$$

Keterangan

a : berat biomassa

$\mathrm{b}$ : berat gula reduksi awal

c : berat gula reduksi setelah fermentasi

\section{HASIL DAN PEMBAHASAN}

\section{pH Akhir Fermentasi}

Hasil analisis sidik ragam menunjukkan bahwa perlakuan kultivasi statis berpengaruh sangat nyata $(\mathrm{P}<0,01)$, terhadap $\mathrm{pH}$ akhir fermentasi limbah padat brem. $\mathrm{pH}$ akhir fermentasi yang dihasilkan pada perlakuan kultivasi statis pada 0 hari mendapatkan nilai sebesar $(2,97 \pm 0,08)$ yang tidak berbeda nyata dengan kultivasi statis 3 hari yaitu $(2,98 \pm 0,05)$ tetapi menunjukkan perbedaan yang nyata pada kultivasi statis 1 hari yaitu $(3,18 \pm 0,05)$ dan 2 hari yaitu $(3,38$ $\pm 0,10)$. 


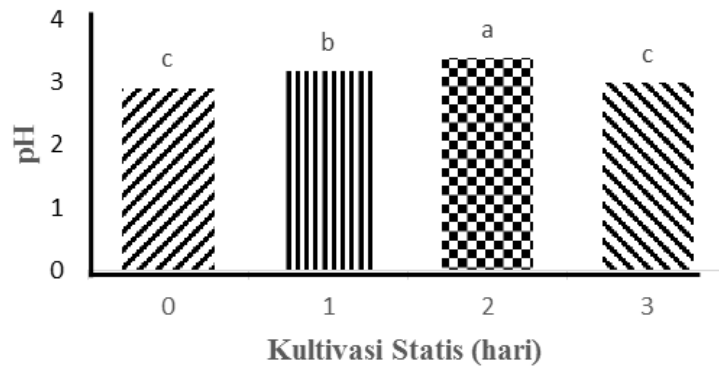

Gambar 1. Nilai rata-rata $\mathrm{pH}$ akhir dari fermentasi limbah padat brem dengan kultivasi statis berbeda selama fermentasi. Huruf yang sama di atas grafik menunjukkan perbedaan yang tidak nyata pada uji beda Duncan 5 persen

Selama proses fermentasi terjadi kenaikan $\mathrm{pH}$ untuk semua lama kultivasi statis dari $\mathrm{pH}$ awal media fermentasi $(2,0)$. Setelah fermentasi pada perlakuan kultivasi statis 0 hari sampai perlakuan kultivasi statis 2 hari terjadi peningkatan $\mathrm{pH}$, sedangkan setelah fermentasi pada kultivasi statis 3 hari terjadi penurunan $\mathrm{pH}$. Pada penelitian ini tidak menggunakan penyangga $\mathrm{pH}$, sehingga terjadi peningkatan $\mathrm{pH}$ dari $\mathrm{pH}$ awal media. Menurut Carolina et al. (2015), pada fermentasi asam sitrat menggunakkan molase, penurunan $\mathrm{pH}$ terjadi selama waktu fermentasi. Hal ini dimungkinkan terjadi karena adanya reaksi penyangga $\mathrm{pH}$ dan terbentuknya asam-asam lemah yang membentuk buffer dengan garamnya.

Nilai $\mathrm{pH}$ juga dipengaruhi oleh produk yang dihasilkan selama proses fermentasi. Dalam penelitian ini, produk fermentasi yang dihasilkan adalah asam sitrat. Menurut Poesponegoro \& Liang (1991), proses fermentasi asam sitrat memerlukan $\mathrm{pH}$ awal yang rendah untuk merangsang akumulasi asam sitrat. Namun penerapan $\mathrm{pH}$ awal media yang rendah ini cenderung menghambat perkecambahan spora dan pertumbuhan Aspergillus niger. Selain itu, Shadafza et al. (1976) juga mengemukakan bahwa $\mathrm{pH}$ awal yang tinggi dapat memicu akumulasi produk lain, yaitu asam oksaloasetat.

\section{Total padatan terlarut}

Hasil analisis sidik ragam menunjukkan bahwa perlakuan kultivasi statis berpengaruh sangat nyata $(\mathrm{P}<0,01)$ terhadap total padatan terlarut fermentasi limbah padat brem. Nilai rata-rata total padatan terlarut yang dihasilkan pada perlakuan kultivasi statis 0 hari mendapatkan nilai tertinggi $(13,03$ persen $\pm 0,05)$ yang tidak berbeda nyata dengan kultivasi statis 1 hari yaitu $(13,00$ persen $\pm 0,00)$ dan kultivasi statis 2 hari yaitu $(12,68$ persen $\pm 0,36)$ tetapi menunjukkan perbedaan yang nyata pada kultivasi statis 3 hari yaitu $(12,13$ persen \pm $0,10)$.

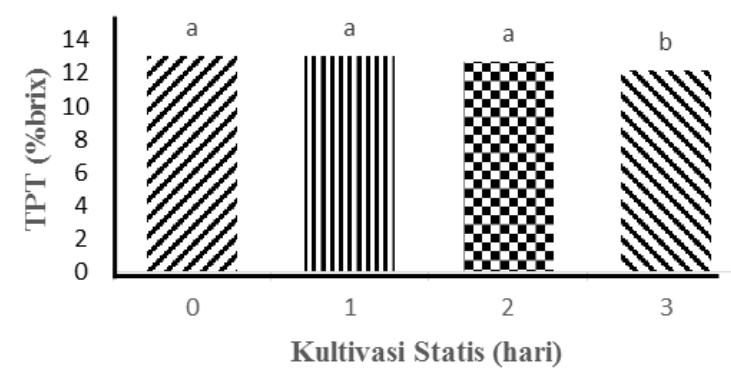

Gambar 2. Nilai rata-rata total padatan terlarut (TPT) akhir fermentasi limbah padat brem dengan kultivasi statis yang berbeda. Huruf yang sama di atas grafik menunjukkan perbedaan yang tidak nyata pada uji beda Duncan 5 persen

Gambar 2 menunjukkan penurunan nilai total padatan terlarut akhir setelah fermentasi asam sitrat. Menurunnya total padatan terlarut terjadi selama proses fermentasi berlangsung disebabkan karena gula yang merupakan komponen dominan dalam medium dimetabolisme oleh kapang menjadi asam organik. Asam organik kemudian dimanfaatkan oleh kapang Aspergillus niger sebagai sumber karbon untuk memproduksi asam sitrat sehingga 
total padatan terlarut menjadi menurun. Hal ini diperkuat dengan pernyataan Sutarmi (2005), bahwa selama proses fermentasi khamir dan kapang melakukan metabolisme glukosa menjadi asam-asam organik.

\section{Gula reduksi}

Hasil analisis sidik ragam menunjukkan bahwa perlakuan kultivasi statis berpengaruh sangat nyata $(\mathrm{P}<0,01)$ terhadap gula reduksi fermentasi hidrolisat cair limbah padat brem. Nilai rata-rata gula reduksi terendah terdapat pada perlakuan kultivasi statis 3 hari yaitu $(11,34 \pm 0,06)$ yang berbeda nyata dengan perlakuan kultivasi statis 2 hari $(11,85 \pm 0,16)$ dengan perlakuan kultivasi statis 1 hari $(12,14 \pm 0,07)$ dan perlakuan kultivasi statis 0 hari yaitu $(12,84 \pm 0,05)$.

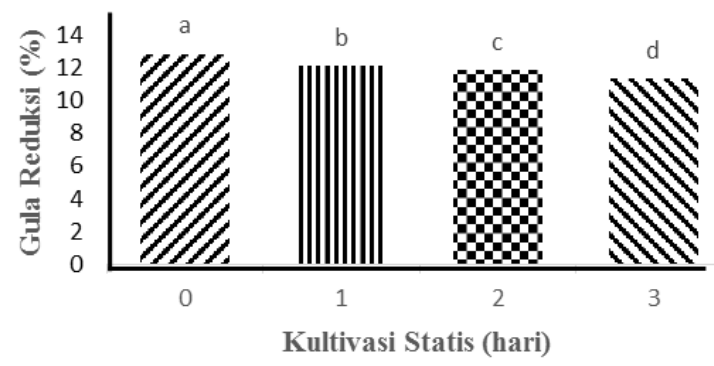

Gambar 3. Nilai rata-rata gula reduksi fermentasi limbah padat brem dengan kultivasi statis yang berbeda. Huruf yang berbeda di atas grafik menunjukkan perbedaan yang nyata pada uji Duncan 5 persen

Gambar 3 menunjukkan penurunan nilai rata-rata gula reduksi pada perlakuan kultivasi statis fermentasi asam sitrat. Menurunnya gula reduksi terjadi selama proses fermentasi berlangsung, hal ini mengindikasikan bahwa gula telah dikonsumsi mikroba. Menurut (Sasmitaloka, 2017) produksi asam sitrat akan terus meningkat sampai nutrisi yang terkandung dalam media habis. Semakin lama waktu fermentasi yang berlangsung, maka kadar nutrisi yang terkandung dalam media akan semakin habis dan kadar gula sisa yang ada dalam media akan semakin menurun.

\section{Biomassa}

Hasil analisis ragam menunjukkan bahwa perlakuan kultivasi statis berpengaruh sangat nyata $(\mathrm{P}<0,01)$ terhadap biomassa fermentasi limbah padat brem. Biomassa yang dihasilkan pada perlakuan kultivasi statis 3 hari mendapatkan nilai tertinggi $(36,05 \pm 0,02)$ yang tidak berbeda nyata dengan perlakuan kultivasi statis 2 hari $(35,29 \pm 0,07)$ dan kultivasi statis 1 hari $(35,24 \pm 0,07)$ tetapi menunjukkan perbedaan yang nyata pada perlakuan kultivasi statis 0 hari $(32,94 \pm 0,02)$.

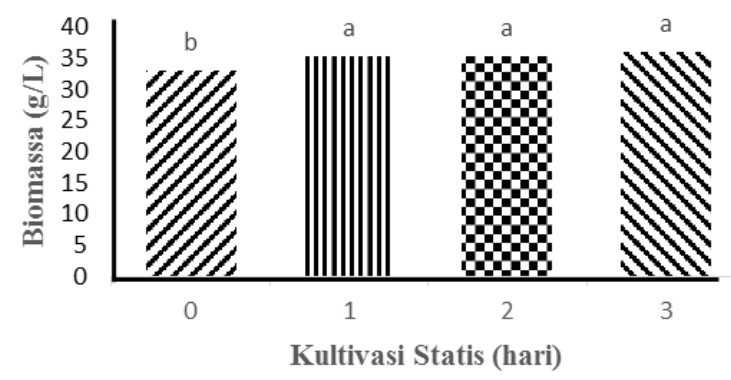

Gambar 4. Nilai rata-rata biomassa fermentasi limbah padat brem dengan kultivasi statis berbeda. Huruf yang sama di atas grafik menunjukkan perbedaan yang tidak nyata pada uji beda Duncan 5 persen

Gambar 4 menunjukkan peningkatan nilai rata-rata biomassa Aspergillus niger ATCC 16404 pada perlakuan kultivasi statis fermentasi asam sitrat. Biomassa yang dihasilkan pada perlakuan kultivasi statis 3 hari mendapatkan nilai tertinggi $(36,05 \pm$ $0,21)$ yang tidak berbeda nyata dengan perlakuan kultivasi statis 2 hari $(35,29 \pm 0,74)$ dan kultivasi statis 1 hari $(35,24 \pm 0,72)$ tetapi menunjukkan perbedaan yang nyata pada perlakuan kultivasi statis 0 hari $(32,94 \pm$ 0,20). Dapat disimpulkan bahwa perlakuan kultivasi statis 1 hari cukup untuk proses awal 
dilakukan fermentasi dengan cara digojog pada produksi asam sitrat. Penggunaan kultivasi statis pada medium fermentasi adalah untuk memberikan waktu beradaptasi, sehingga adanya fase adaptasi tersebut maka fase pertumbuhan akan lebih maksimal, hal ini juga ditunjukkan dengan hasil penelitian dimana biomassa yang terbentuk pada perlakuan kultivasi statis menunjukkan perbedaan yang signifikan. Kenaikan biomassa disebabkan karena pada proses fermentasi, kapang Aspergillus niger mengkonsumsi glukosa sebagai sumber karbon untuk memproduksi asam sitrat (Betiku \& Adesina, 2013). Hal ini dapat dilihat pada hasil analisis gula reduksi dan total padatan terlarut yang menunjukkan penurunan selama proses fermentasi.

\section{Produksi Ca-Sitrat, Asam Sitrat, dan Yield}

Hasil analisis sidik ragam menunjukkan bahwa perlakuan kultivasi statis berpengaruh sangat nyata $(\mathrm{P}<0,01)$ terhadap produksi Ca-sitrat, yield Ca-sitrat, asam sitrat, yield asam sitrat dan yield biomassa pada proses fermentasi limbah padat brem. Nilai rata-rata hasil produksi Casitrat, yield Ca-sitrat, perhitungan stoikiometri asam sitrat dan yield asam sitrat dapat dilihat pada Tabel 1, serta nilai rata-rata yield biomassa dapat dilihat pada Tabel 2 .

Hasil penelitian menunjukkan bahwa perlakuan kultivasi statis memperlihatkan peningkatan produksi Ca-sitrat fermentasi limbah padat brem setelah kultivasi statis 1 hari. Nilai rata-rata produksi Ca-sitrat fermentasi limbah padat brem dapat dilihat pada Tabel 1. Serta hasil analisis ragam menunjukkan bahwa perlakuan kultivasi statis berpengaruh sangat nyata $(\mathrm{P}<0,01)$ terhadap Ca-sitrat hasil fermentasi limbah padat brem.

Tabel 1. Nilai rata-rata produksi Ca-sitrat, yield $\mathrm{Ca}$-sitrat, asam sitrat, dan yield asam sitrat.

\begin{tabular}{llllll}
\hline $\begin{array}{l}\text { Kultivasi } \\
\text { Statis (hari) }\end{array}$ & $\begin{array}{l}\text { Ca-Sitrat } \\
(\mathrm{g} / \mathrm{L})\end{array}$ & Yield Ca-Sitrat & $\begin{array}{l}\text { Asam Sitrat } \\
(\mathrm{g} / \mathrm{L})\end{array}$ & $\begin{array}{l}\text { Yield } \\
\text { Sitrat }\end{array}$ & $\begin{array}{l}\Delta \text { Gula Reduksi } \\
(\mathrm{g} / \mathrm{L})\end{array}$ \\
\hline 0 & $3,77 \pm 0,06 \mathrm{a}$ & $0,074 \pm 0,001 \mathrm{a}$ & $2,09 \pm 0,03 \mathrm{~b}$ & $0,041 \pm 0,000 \mathrm{a}$ & $128,4 \pm 0,52 \mathrm{a}$ \\
1 & $3,84 \pm 0,05 \mathrm{~b}$ & $0,067 \pm 0,001 \mathrm{~b}$ & $2,12 \pm 0,03 \mathrm{~b}$ & $0,037 \pm 0,001 \mathrm{~b}$ & $121,4 \pm 0,69 \mathrm{~b}$ \\
2 & $3,90 \pm 0,07 \mathrm{~b}$ & $0,064 \pm 0,002 \mathrm{bc}$ & $2,16 \pm 0,04 \mathrm{~b}$ & $0,036 \pm 0,001 \mathrm{~b}$ & $118,5 \pm 1,59 \mathrm{c}$ \\
3 & $4,08 \pm 0,08 \mathrm{~b}$ & $0,062 \pm 0,002 \mathrm{c}$ & $2,26 \pm 0,05 \mathrm{a}$ & $0,034 \pm 0,001 \mathrm{~b}$ & $113,4 \pm 0,64 \mathrm{~d}$ \\
\hline
\end{tabular}

Keterangan: Data merupakan nilai rata-rata dari 4 kelompok dengan simpangan bakunya (SD). Huruf yang sama di belakang nilai rata-rata menunjukkan perbedaan yang tidak nyata pada uji beda Duncan 5 persen

Tabel 1 menunjukkan bahwa nilai ratarata produksi Ca-sitrat hasil fermentasi limbah padat brem dan yield Ca-sitrat pada perlakuan kultivasi statis berbeda. Ca-sitrat yang dihasilkan pada perlakuan kultivasi statis 3 hari mendapatkan nilai tertinggi $(4,08$ $\pm 0,08)$ yang tidak berbeda nyata dengan kultivasi statis 2 hari yaitu $(3,90 \pm 0,07)$ dan kultivasi statis 1 hari yaitu $(3,84 \pm 0,05)$ tetapi menunjukkan perbedaan yang nyata pada kultivasi statis 0 hari yaitu $(3,77 \pm 0,06)$. Yield Ca-sitrat yang dihasilkan pada perlakuan kultivasi statis 0 hari mendapatkan nilai tertinggi $(0,074 \pm 0,001)$ yang berbeda nyata dengan kultivasi statis 1 hari $(0,067 \pm$ $0,001)$ dengan kultivasi statis 2 hari $(0,064 \pm$ $0,002)$ dan kultivasi statis 3 hari $(0,062 \pm$ $0,002)$. 
Tabel 2. Nilai rata-rata biomassa, dan yield biomassa.

\begin{tabular}{llll}
\hline $\begin{array}{l}\text { Kultivasi } \\
\text { Statis (hari) }\end{array}$ & Biomassa (g/L) & Yield Biomassa & $\Delta$ Gula Reduksi (g/L) \\
\hline 0 & $32,94 \pm 0,20 \mathrm{~b}$ & $0,649 \pm 0,007 \mathrm{a}$ & $128,4 \pm 0,52 \mathrm{a}$ \\
1 & $35,24 \pm 0,72 \mathrm{a}$ & $0,611 \pm 0,015 \mathrm{~b}$ & $121,4 \pm 0,69 \mathrm{~b}$ \\
2 & $35,29 \pm 0,74 \mathrm{a}$ & $0,582 \pm 0,023 \mathrm{bc}$ & $118,5 \pm 1,59 \mathrm{c}$ \\
3 & $36,05 \pm 0,29 \mathrm{a}$ & $0,549 \pm 0,006 \mathrm{c}$ & $113,4 \pm 0,64 \mathrm{~d}$
\end{tabular}

Keterangan: Data merupakan nilai rata-rata dari 4 kelompok dengan simpangan bakunya (SD). Huruf yang sama di belakang nilai rata-rata menunjukkan perbedaan yang tidak nyata pada uji beda Dunca 5 persen

Tabel 2 menunjukkan bahwa nilai ratarata yield biomassa pada perlakuan kultivasi statis berbeda. Yield biomassa yang dihasilkan pada perlakuan kultivasi statis 0 hari mendapatkan nilai tertinggi $(0,649 \pm$ $0,007)$ yang berbeda nyata dengan perlakuan kultivasi statis 1 hari $(0,611 \pm 0,015)$ dengan kultivasi statis 2 hari $(0,582 \pm 0,023)$ dan kultivasi statis 3 hari $(0,549 \pm 0,006)$.

Dari hasil penelitian menunjukkan bahwa efisiensi produksi asam sitrat, dilihat dari yield biomassa dengan asam sitrat, lebih tinggi pada perlakuan tanpa kultivasi statis $(0$ hari) dibandingkan dengan dilakukan kultivasi statis (1, 2, 3 hari). Pada kultivasi statis memperlihatkan pemanfaatan gula yang lebih tinggi dalam proses fermentasi, sehingga produksi asam sitrat dan pertumbuhan biomassa lebih tinggi dibandingkan tanpa dilakukan kultivasi statis (0 hari). Kultivasi statis 2 hari dan 3 hari memperlihatkan produksi Ca-sitrat (asam sitrat) dan biomassa yang tidak berbeda nyata dengan kultivasi statis 1 hari. Dari hasil penelitian ini dapat dinyatakan bahwa untuk adaptasi pertumbuhan miselia Aspergillus niger ATCC 16404 hanya diperlukan waktu statis 1 hari.

Tingginya kadar Ca-sitrat diduga karena Aspergillus niger ATCC 16404 tumbuh secara optimal dan selama waktu fermentasi gula terkonversi menjadi asam oleh mikroba dalam hidrolisat tepung limbah padat brem yang difermentasi. Afifah (2010) menyatakan bahwa selama proses fermentasi, khamir, kapang, dan bakteri melakukan metabolisme sukrosa, yang menghasilkan asam-asam organik. Berat Ca-sitrat yang telah diperoleh berdasarkan perlakuan terbaik kemudian dikonversikan menjadi berat asam sitrat equvalen dengan menggunakan perhitungan stoikiometri, sehingga diperoleh berat asam sitrat sebesar 2,12 $\pm 0,03 \mathrm{~g} / \mathrm{L}$. Papagianni et al., (1999) menyatakan bahwa $\mathrm{pH}$ mempengaruhi morfologi dan produktivitas asam sitrat dari Aspergillus niger dari hasil data kuantitatif. Morfologi dengan agregat yang kecil dan filamen yang pendek berkaitan dengan meningkatnya produksi asam sitrat pada $\mathrm{pH}$ sekitar 2,0 \pm 0,2 .

\section{KESIMPULAN DAN SARAN}

\section{Simpulan}

Berdasarkan penelitian yang telah dilakukan maka dapat disimpulkan beberapa hal sebagai berikut:

1. Perlakuan kultivasi statis berpengaruh sangat nyata terhadap kadar Ca-sitrat, derajat keasaman, total padatan terlarut, gula reduksi, biomassa, yield Ca-sitrat, dan yield biomassa hasil fermentasi tepung limbah padat brem menggunakan Aspergillus niger ATCC 16404.

2. Perlakuan kultivasi statis 1 hari cukup untuk proses awal dilakukan fermentasi dengan cara digojog pada produksi asam sitrat dan menghasilkan Ca-sitrat sebanyak 3,84 $\pm 0,05 \mathrm{~g} / \mathrm{L}$ dan pada 
perhitungan stoikiometri, asam sitrat yang dihasilkan pada kultivasi 1 hari sebanyak $2,12 \pm 0,03$

\section{Saran}

Perlu dilakukan penelitian lebih lanjut mengenai kultivasi kultur Aspergillus niger ATCC 16404 terhadap produksi asam sitrat dengan menambahkan faktor-faktor lain sebagai perlakuan seperti lama kultivasi statis pada jarak 0 sampai 24 jam, suhu fermentasi, menggunakan penyangga $\mathrm{pH}$ pada proses fermentasi dan kecepatan shaker dalam proses fermentasi untuk meningkatkan konsentrasi oksigen dan mendapatkan kadar asam sitrat yang lebih banyak.

\section{DAFTAR PUSTAKA}

Afifah, N. 2010. Analisis kondisi dan potensi lama fermentasi medium kombucha (teh, kopi, rosella) dalam menghambat pertumbuhan bakteri pathogen (Vibrio cholera dan Bacillus cereus). Skripsi. Tidak dipublikasikan. Universitas Islam Negeri. Malang.

Ali, S., U. H. Ikram, M. A. Qadeer, dan J. Iqbal, 2002. Production of citric acid by Aspergillus niger using cane molasses in a stirred fermentor. Electronic Journal of Biotechnology 5(3): 125 132

AOAC, Assosiation of Official Analytical Chemist. 1990. Official Methods of Analysis. Method 986-29, $15^{\text {th }}$ Edition. Washington D.C.

Azhary, H. R. Ovelando, M. A. Nabilla. 2013. Fermentasi Buah Markisa (Passiflora) Menjadi Asam Sitrat. Jurnal Teknik Kimia. 9(3): 15 - 21

Betiku, E. dan O.A. Adesina. 2013. Optimization of sweet potato starch hydrolyzate production and its potential utilization as substrate for citric acid production. British Biotechnology Journal 3(2): 169 - 182.

Carolina, A., A. Sidik, I.P. Maksum, S.D. Rachman, A. Safari, dan S. Ishmayana. 2015. Fermentasi biak rendam molasses dengan Aspergillus niger untuk produksi asam sitrat. Chimica et Natura Acta. 3(1): 25 - 29.

Darmataba, N. S. Antara, dan G. P. Ganda, 2017. Pengaruh Konsentrasi Substrat Tepung Limbah Brem dan Lama Fermentasi Terhadap Produksi Kalsium Sitrat dengan Menggunakan Aspergillus niger ATCC 16404. Jurnal REKAYASA DAN MANAJEMEN AGROINDUSTRI. 5(1): 50 - 59.

Harijono, J. Kusnadi, dan S.A. Mustikasari. 2001. Pengaruh kadar karagenan dan total padatan terlarut sari buah apel muda terhadap aspek kualitas permen jelly. Jurnal Teknologi Pertanian. 2(2): $110-116$

Mattey, M. 1992. The Production of Organic Acids. Crit Rev Biotechnol. 12, 87 132.

Papagianni, M.; Mattey, M.; Berovic, M.; Kristiansen, B. 1999. Aspergillus niger Morphology and Citric Acid Production in Submerged Batch Fermentation: Effects of Culture $\mathrm{pH}$, Phosphate and Manganese Levels. Food Technol Biotechnol. 37, 165 171.

Papagianni. M. 1995. Morphology and Citric Acid Production of Aspergillus niger in Submerged Culture. Tesis Doktor, University of Strathclyde.

Pertiwi, L. P. Wrasiati, dan W. Arnata. 2016. Pemanfaatan Ampas Padat Brem Cair Menjadi Gula Cair. Jurnal REKAYASA DAN MANAJEMEN AGROINDUSTRI. 4(4): 49 - 58. 
Poesponegoro, M. dan Liang, O.B. 1991. Fermentasi asam sitrat dari tetes tebu secara biak rendam dengan Aspergillus niger, Jurnal Kimia Terapan Indonesia. 1(2): $35-40$.

Sasmitaloka, K. 2017. Produksi Asam Sitrat Oleh Aspergillus niger Pada Kulltivasi Media Cair.Jurnal Integrasi Proses. 6(3): $116-122$.

Shadafza, D., T. Ogawa, dan A. Fazeli. 1976. Comparison of citric acid production from beet molasses and date syrup with Aspergillu niger, Journal of Fermentation Technology. 54: 67 - 75 .

Sumo, Sumantri, Subono, 1993. Prinsip Bioteknologi. PT. Gramedia Pustaka Utama, Jakarta.

Sudarmadji, S., Haryono, dan B. Suhardi. 1997. Prosedur Analisis untuk Bahan Makanan dan Penelitian. Liberty, Yogyakarta

Sutarmi, 2005. Pengembangan produk kombucha probiotik berbahan baku the hijau dan the oolong. Skripsi. Tidak dipublikasikan. Departemen Ilmu dan Teknologi Pangan. Fakultas Teknologi Pertanian. Institut Pertanian Bogor.
Suwariani, 2016. Hidrolisis Bungkil Biji Jarak Pagar Menjadi Hidrolisat Cair Dan Aplikasinya Sebagai Medium Produksi Lipase Oleh Aspergillus niger 65 I6 Dengan Sistem Submerged Fermentation. Tesis. Tidak dipublikasikan. Program Studi Bioteknologi. Universitas Gadjah Mada.

Ulfa, B. 1996. Studi tentang penambahan tepung ubi kayu dan jenis gula dalam pembuatan dodol limbah padat brem. Skripsi. Tidak dipublikasikan. Jurusan Teknologi Hasil Pertanian. Fakultas Pertanian. Universitas Widyagama Malang.

Wagestu, N. S. Antara, dan G. P. Ganda. 2017. Pengaruh $\mathrm{pH}$ Awal Media dan Lama Fermentasi Terhadap Produksi Kalsium Sitrat dari Limbah Brem Dengan Menggunakan Aspergillus niger ATCC 16404. Jurnal REKAYASA DAN MANAJEMEN AGROINDUSTRI. 4(4): 70 - 79.

Winarno, F.G. 1984. Kimia Pangan dan Gizi. PT. Gramedia Pustaka Utama, Jakarta 